\title{
Railway deformation detected by DInSAR over active sinkholes in the Ebro Valley evaporite karst, Spain
}

\author{
J. P. Galve ${ }^{1}$, C. Castañeda ${ }^{2}$, and F. Gutiérrez ${ }^{3}$ \\ ${ }^{1}$ Departamento de Geodinámica, Universidad de Granada, Campus de Fuentenueva s/n, 18071 Granada, Spain \\ ${ }^{2}$ Estación Experimental de Aula Dei, EEAD-CSIC, Ave. Montañana 1005, 50059 Zaragoza, Spain \\ ${ }^{3}$ Departamento de Ciencias de la Tierra, Universidad de Zaragoza, C/Pedro Cerbuna 12, 50009 Zaragoza, Spain
}

Correspondence to: J. P. Galve (jpgalve@ugr.es)

Received: 25 May 2015 - Published in Nat. Hazards Earth Syst. Sci. Discuss.: 16 June 2015

Revised: 6 October 2015 - Accepted: 18 October 2015 - Published: 2 November 2015

\begin{abstract}
Subsidence was measured for the first time on railway tracks in the central sector of Ebro Valley (NE Spain) using Differential Synthetic Aperture Radar Interferometry (DInSAR) techniques. This area is affected by evaporite karst and the analysed railway corridors traverse active sinkholes that produce deformations in these infrastructures. One of the railway tracks affected by slight settlements is the Madrid-Barcelona high-speed line, a form of transport infrastructure highly vulnerable to ground deformation processes. Our analysis based on DInSAR measurements and geomorphological surveys indicates that this line shows dissolution-induced subsidence and compaction of anthropogenic deposits (infills and embankments). Significant sinkhole-related subsidence was also measured by DInSAR techniques on the Castejón-Zaragoza conventional railway line. This study demonstrates that DInSAR velocity maps, coupled with detailed geomorphological surveys, may help in the identification of the railway track sections that are affected by active subsidence.
\end{abstract}

\section{Introduction}

Human infrastructures located in karst environments may be affected by severe ground instability problems (Waltham et al., 2005; Gutiérrez et al., 2014). In particular, the occurrence and activity of sinkholes in carbonate and evaporite karst terrains is one of the main causes of subsidence-related damage and accidents on conventional railways (Guerrero et al., 2008). Deflections in the railway track caused by dissolution- induced settlement can compromise safety on transportation infrastructure (Gourc et al., 1999). The implementation of monitoring and early-warning systems on potentially problematic railway stretches may constitute an effective mitigation measure, mainly aimed at preventing accidents. Differential Synthetic Aperture Radar Interferometry (DInSAR) may be postulated as a useful subsidence monitoring technique for railways. Most of the reported Interferometric Synthetic Aperture Radar (InSAR) applications to the monitoring of high-speed railways (HSR) have been developed in China and Taiwan. In these countries, railway and highway infrastructure are experiencing rapid development and they traverse numerous areas affected by ground instability phenomena (Ge et al., 2008, 2009; Hung et al., 2010; Shi et al., 2010; Tan et al., 2010; Wu et al., 2010; Zhang et al., 2010; Chen et al., 2012; Ge et al., 2013). The instability processes that produce most problems on Chinese railways, and are the main targets of InSAR analyses, are related to groundwater abstraction (Hung et al., 2010; Zhang et al., 2010) and permafrost (Chen et al., 2013; Shi et al., 2014). For a railway built upon permafrost, Shi et al. (2014) documented temporal variations of deformation in relation to rainfall and air temperature, and measured higher strain in topographically lower areas, where water accumulation increases the impact of thawing and freezing. Further, the activity of sinkholes has been monitored using DInSAR in different geological settings of Germany (Schäffer, 2009), Israel (Baer at el., 2002; Abelson et al., 2003; Nof et al., 2013), Italy (Ferretti et al., 2000, 2004), Jordan (Closson et al., 2005, 2010), Spain 


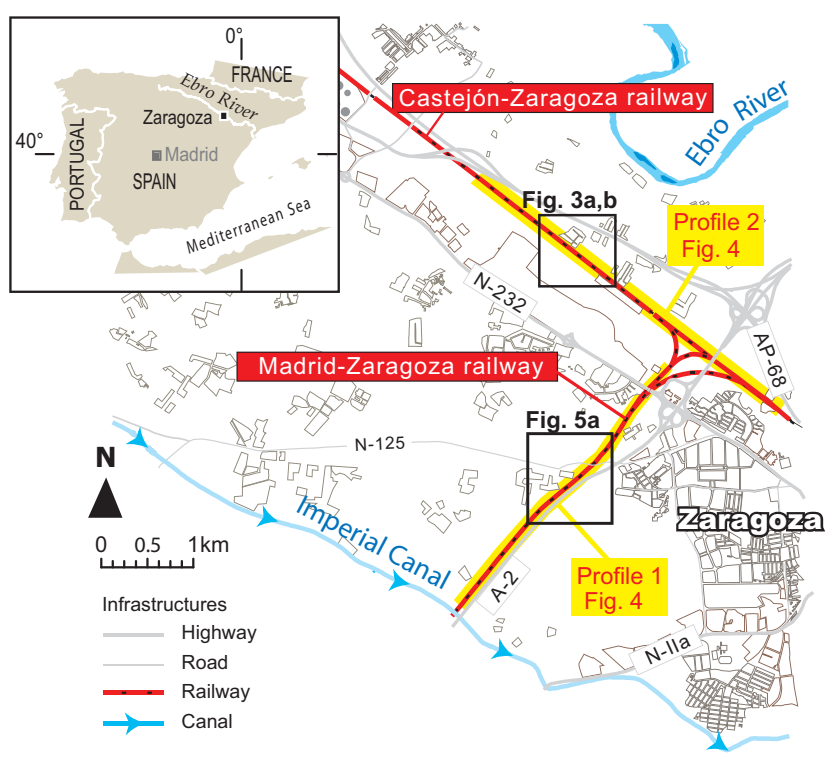

Figure 1. Geographic location of the studied railway sections.

(Castañeda et al., 2009, 2011, Gutiérrez et al., 2011, Galve et al., 2015) and USA (Al-Fares, 2005, Paine et al., 2012).

Here, we present DInSAR displacement profiles that reveal previously undetected active subsidence on sections of different railways in the surroundings of Zaragoza, Ebro Valley evaporite karst, NE Spain (Fig. 1). The Cenozoic bedrock in the analysed area of the Ebro Valley consists of subhorizontally lying halite- and glauberite-bearing evaporites of the Zaragoza Formation (Salvany et al., 2007) (Fig. 2). Subsurface dissolution results in the development of numerous sinkholes affecting both the evaporitic bedrock and the alluvial cover (Galve et al., 2009; Pueyo-Anchuela et al., 2015, and references therein). Active subsidence associated with these sinkholes causes costly damage to man-made structures (e.g. Gutiérrez et al., 2009, 2015). The dissolution-induced ground deformation can be studied quantitatively using InSAR techniques as illustrated by previous works (cf., Castañeda et al., 2009, 2011; Gutiérrez et al., 2011; Galve et al., 2015).

We have analysed two railway stretches. One of them includes two parallel railways, a conventional one and the Madrid-Barcelona high-speed line. Here, $1850 \mathrm{~m}$ and $1900 \mathrm{~m}$ long sections are built on embankments and in excavated trenches, respectively. The latter are flanked by cuttings that expose subsidence structures. The other stretch with active subsidence includes a $4000 \mathrm{~m}$ long section of the conventional Castejón-Zaragoza railway (Fig. 1). Both railway corridors traverse large sinkholes previously documented in geomorphological maps (Simón et al., 1998, 2003; Galve et al., 2009). Some of these sinkholes were defined as being active on the basis of surficial signs of settlement and on the occurrence of collapses within them. For example, on 1 March 2003, a collapse sinkhole with $5 \mathrm{~m}$ diameter formed beneath the high-speed railway a few months before its in-
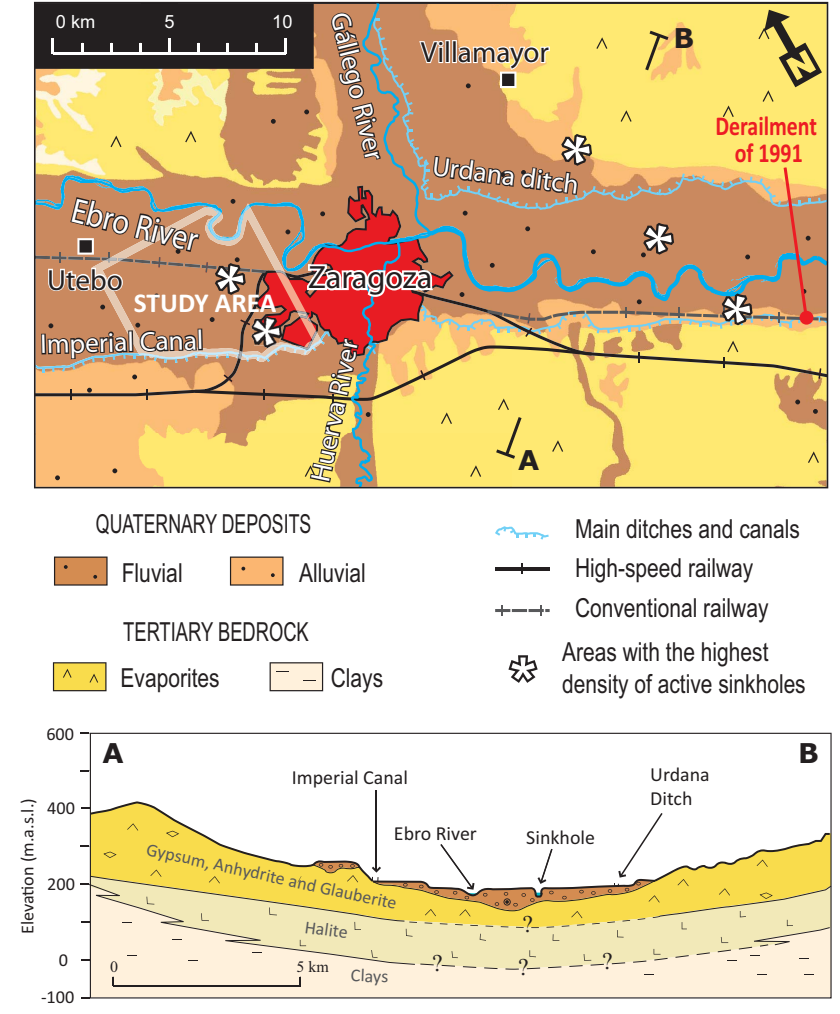

Figure 2. Geological map of the surroundings of Zaragoza and a geological cross section of the central sector of the Ebro Valley. From the geological point of view, the railway tracks crosses the central sector of the Ebro Cenozoic Basin and is underlain by subhorizontally lying evaporites of the Oligo-Miocene Zaragoza Gypsum Formation (Quirantes, 1978). This formation is composed of gypsum, anhydrite, glauberite and halite units (Salvany et al., 2007). Sinkholes are caused by subsurface dissolution and the consequent deformation and/or internal erosion of the overlying sediments. Detailed descriptions of the dissolution and subsidence processes in the study area can be found in Gutiérrez et al. (2008), Galve et al. (2009) and Acero et al. (2015).

auguration (Guerrero et al., 2008). We also observed obvious deformation in a poorly maintained subsidiary railroad of the Castejón-Zaragoza line, coinciding with the location of a sinkhole mapped on the basis of geomorphic criteria (Fig. 3). However, so far the precise area affected by active subsidence has not been identified, nor has its settlement rates been measured. The data obtained by DInSAR analyses represents a step forward in the sinkhole risk analysis for avoiding accidents such as the derailment of a freight train caused by a collapse sinkhole in the conventional Madrid-Barcelona railway on 11 September 1991 (at km 360.7; (Gutiérrez et al., 2007)) (Fig. 2). In this work we integrate DInSAR deformation data with different subsidence evidence (geomorphic, deformed sediments, damaged man-made structures). The convergence of the different lines of evidence is used to support the utility 

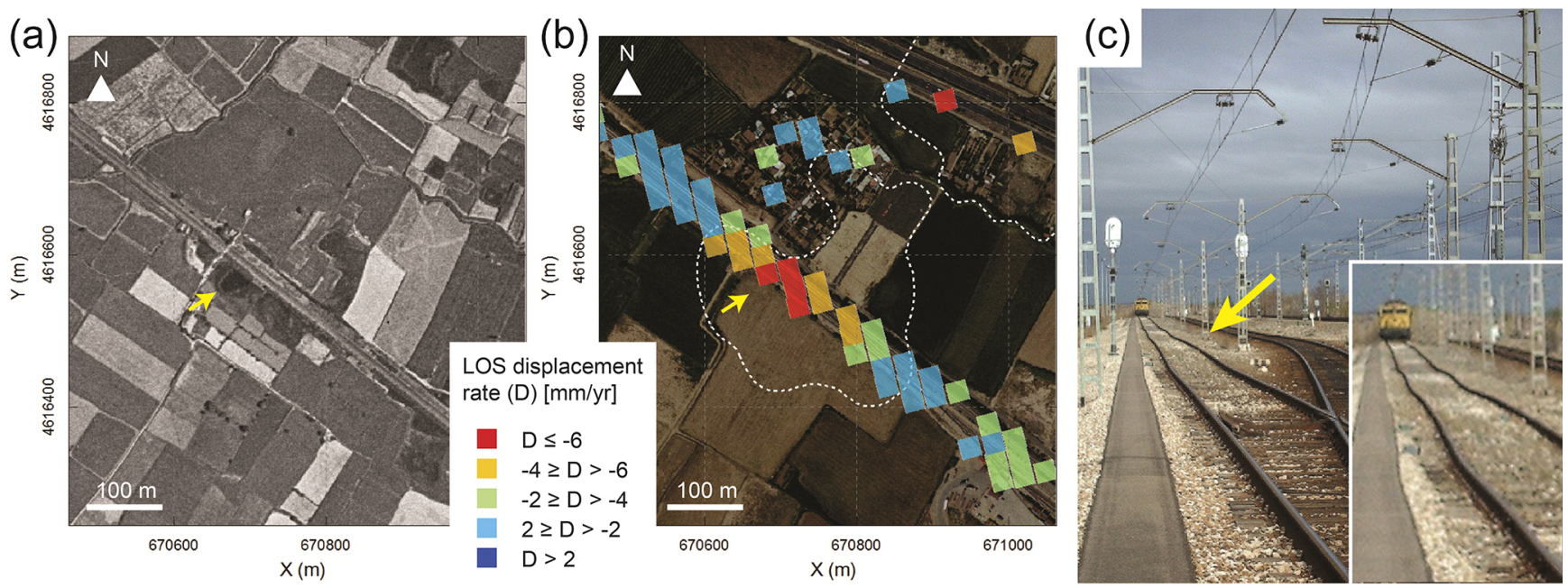

Figure 3. Section of the Castejón-Zaragoza railway built on a buried sinkhole and affected by active karst subsidence. (a) Aerial photograph taken in 1956. Arrow points to a ponded sector within the large subsidence depression. (b) Orthoimage from 2009 with ALOS-derived displacement rates on PSs. Dotted white line defines the boundaries of known active sinkholes. (c) Photographs of the location indicated with arrows in (a) and (b), showing obvious deformation in the railways.

of DInSAR for monitoring railways affected by dissolutioninduced subsidence.

\section{SAR data and processing methods}

Archived data from two orbital SAR (Synthetic Aperture Radar) missions have been used to produce the InSAR deformation maps analysed in this work. One of the data sets includes C-band data of 29 ENVISAT ASAR images acquired at 22:00 on ascending orbits from 2 May 2003 to 17 September 2010 (track 58, frame 829). The other data set comprises L-band data of 13 ALOS PALSAR images acquired at 22:30 in ascending mode and $\mathrm{HH}$ polarization, and it covers a period from 12 February 2007 to 7 April 2010 (track 665, frame 820 ).

The SAR images were processed using the Stable Point Network (SPN) technique (Crosetto et al., 2008). Preprocessing was carried out using the DIAPASON interferometric algorithm (Massonet and Feigl, 1998). This algorithm incorporates the persistent scatterer and distributed scatterer approaches based on full-resolution and medium-resolution data, respectively. The topographic component of the interferometric phase was removed using the Spanish photogrammetric elevation model "GISOleícola" with a spatial resolution of $20 \mathrm{~m}$.

The ENVISAT-ASAR-derived displacement rate map was produced at full resolution from a total of 61 interferograms. The persistent scatterers (PSs) were selected, establishing a coherence threshold of 0.46 on the basis of the SAR amplitude selection criterion. The average line of sight (LOS) displacement rate and the LOS displacement time series of each PS were derived from the Single Look Complex (SLC)
ASAR images. Displacement rate values $>2 \mathrm{~mm} \mathrm{yr}^{-1}$ were considered as non-stable points as it is usually defined for ENVISAT C-band data (Meisina et al., 2008; Bianchini et al., 2013). The ALOS-PALSAR-derived displacement rate map was produced at a ground resolution of about $25 \mathrm{~m} \times 25 \mathrm{~m}$ and a coherence threshold of 0.40 was established. In this case, displacement rates $>4 \mathrm{~mm} \mathrm{yr}^{-1}$ were considered as indicative of surface deformation. This threshold is consistent with values used by other authors (Sandwell et al., 2007; Bianchini et al., 2013). Additional technical information on SAR data sets and DInSAR deformation profiles is listed in Table 1 .

\section{Railway deformation detected by DInSAR and interpretation}

Railways served as good reflection features for ALOS and ENVISAT sensors, providing a relatively high density of measurement points, especially in the ALOS-derived map. Two profiles of LOS displacement rates have been constructed along the railway corridors using the InSAR maps (Fig. 4). We analysed ALOS and ENVISAT data in each profile and selected the best results to be presented in this work: ALOS measurements in the Castejón-Zaragoza railway line, and ENVISAT PS points in the Madrid-Zaragoza profile (Fig. 4).

The displacement rates measured in the SW and NE portions of the analysed Madrid-Zaragoza railway section, as high as $-6.6 \mathrm{~mm} \mathrm{yr}^{-1}$ (negative values indicate subsidence), may be related to compaction of the embankments, as the direct correlation between subsidence rates and embankment height suggests (Fig. 4, Profile 1). LOS displacement rates 

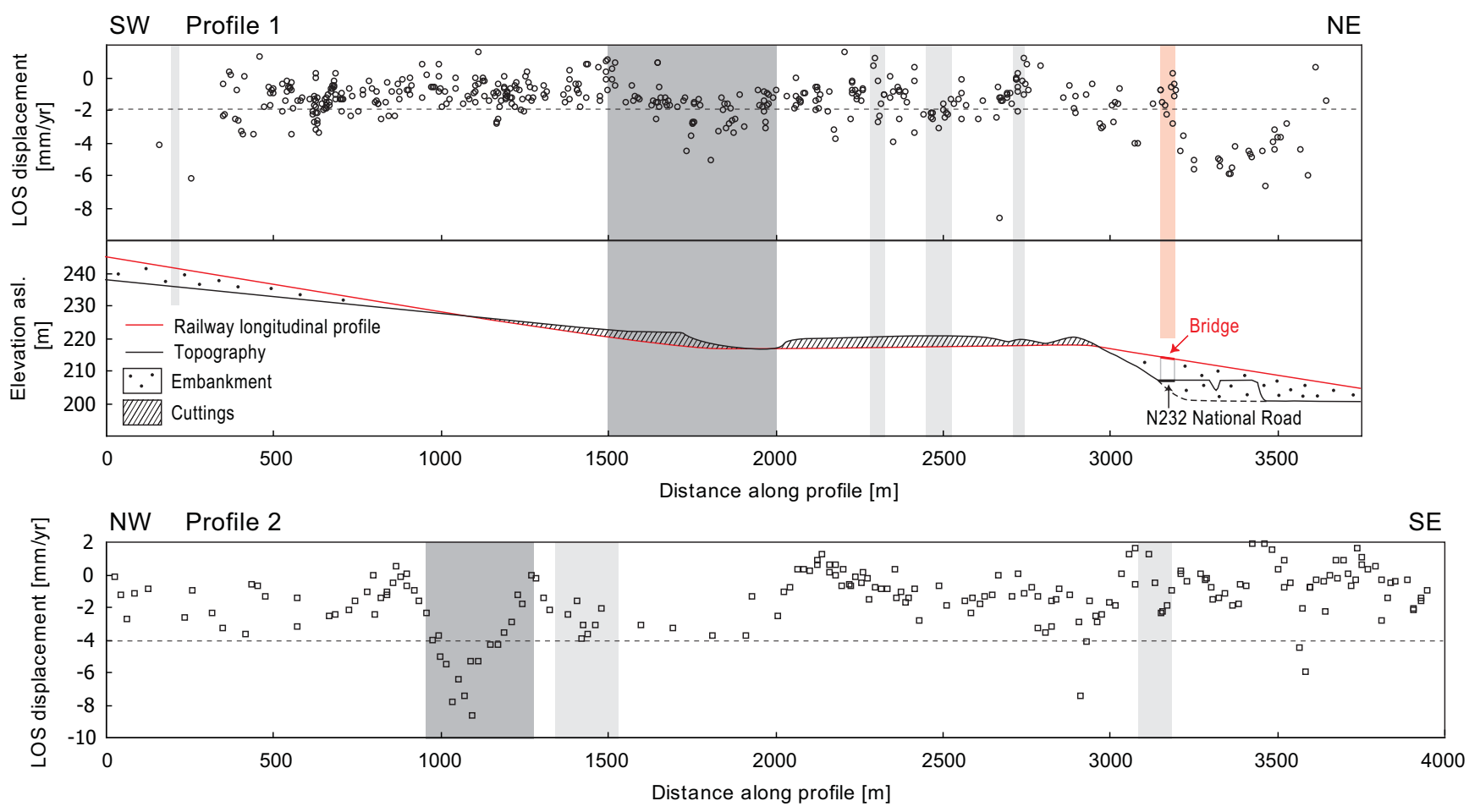

Figure 4. Profiles with DInSAR-derived LOS deformation data obtained along the analysed railway sections. Data from the MadridBarcelona railway corridor are represented alongside a topographic profile showing the stretches built on embankment and excavated trenches. Dark grey and light grey zones indicate sections built on sinkholes classified as being active and inactive, respectively. See location of profiles in Fig. 1.

indicate rapid settlement $\left(>4 \mathrm{~mm} \mathrm{yr}^{-1}\right)$ in the NE sector of the analysed stretch, coinciding with the location of a buried depression of unknown origin, filled a few decades ago and identified with aerial photographs. Here, subsidence is most probably related to compaction of anthropogenic deposits, which may exceed $10 \mathrm{~m}$ including the embankment. However, further investigations would be required to rule out the potential contribution of dissolution-induced subsidence (e.g. trenching, geophysics, vertical extensometers).

The negative LOS displacement values measured in the sector where the path of the railway has been excavated in Quaternary alluvium can be attributed to dissolutioninduced subsidence. There is a significant number of points with LOS displacement rates below $-2 \mathrm{mmyr}^{-1}$ between 1500 and $2700 \mathrm{~m}$ in Profile 1. In this sector, the railways run across subdued sinkholes recognized in old aerial photographs and expressed in cuttings as deformed Quaternary alluvium (Simón et al., 1998, 2003; Galve et al., 2009). The sinkhole cluster comprises a large diffuse-edged depression and several smaller subcircular sinkholes (Galve et al., 2009) (Fig. 5). In addition to the DInSAR deformation data, several lines of evidence consistently indicate active subsidence in some sectors of the sinkhole cluster: enclosed depressions, severe cracking on buildings, conspicuous sags and wide fissures on roads and small collapse sinkholes, including the
2003 event. An excavation carried out at the SW edge of the large depression for the foundation of a bridge exposed tilted Quaternary deposits dipping toward the depression centre (Fig. 5). Two sedimentary packages were distinguished. The lower one corresponds to pre-sinkhole terrace gravel deposits with an apparent NE dip of $14-17^{\circ}$. The upper one corresponds to natural sinkhole fill deposits that pinch out towards the SW (sinkhole edge). The dip of these sediments progressively attenuates upwards (cumulative wedge-out), suggesting synsedimentary subsidence.

The high density of measurement points derived from the ALOS data along the Castejón-Zaragoza railway provides valuable information on the activity of three previously inventoried sinkholes traversed by the infrastructure. A clear subsidence zone, with negative LOS displacement rates as high as $-9.7 \mathrm{~mm} \mathrm{yr}^{-1}$, coincides with a sinkhole of about $300 \mathrm{~m}$ in diameter previously classified as being active (Figs. 3 and 4, Profile 2). Here, ground motion values show a consistent pattern with increasing subsidence rates towards the centre of the sinkhole (Fig. 3). The LOS displacement values measured in the other two sinkholes, previously described as inactive (Galve et al., 2009), suggest ground stability or very slow subsidence $\left(<2 \mathrm{~mm} \mathrm{yr}^{-1}\right)$. 

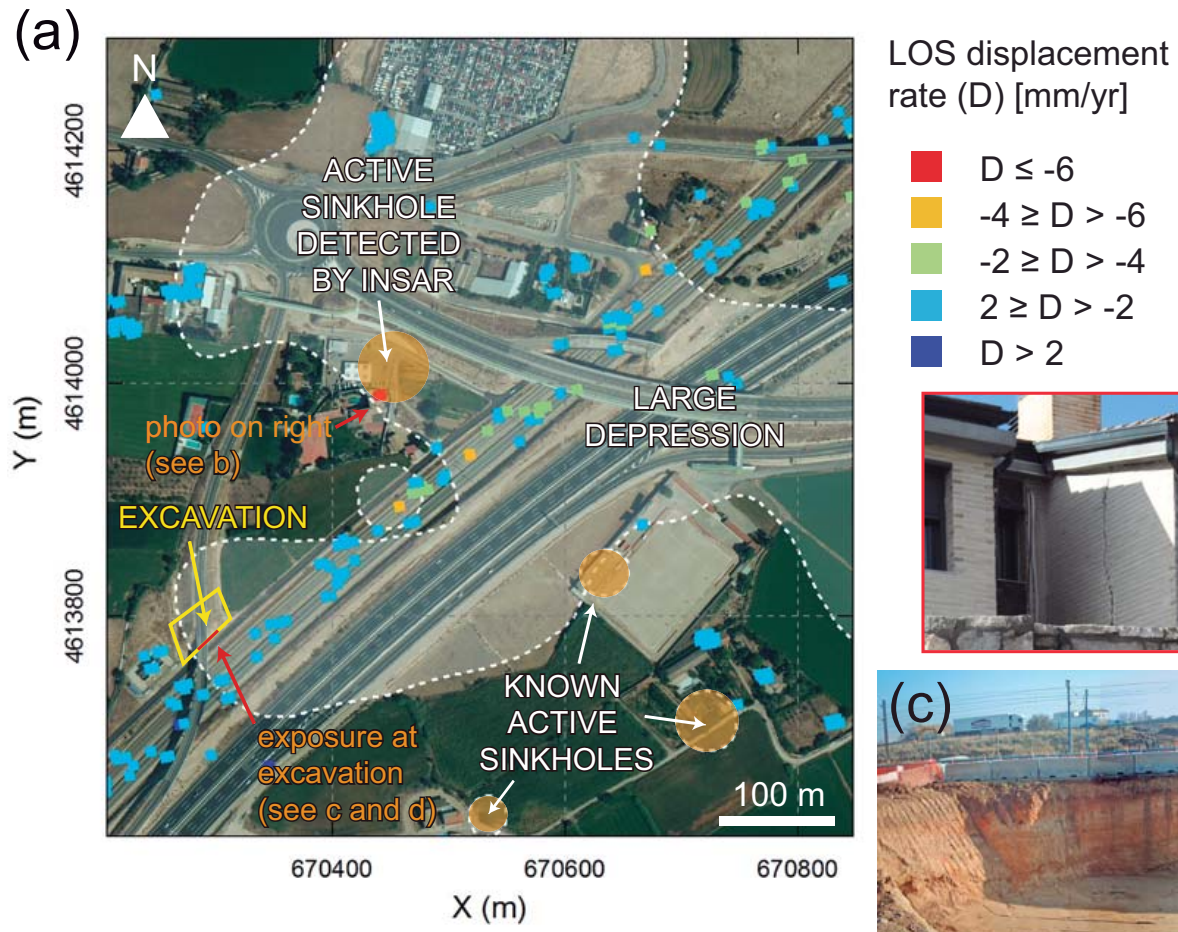

LOS displacement rate (D) $[\mathrm{mm} / \mathrm{yr}]$

$\mathrm{D} \leq-6$

$-4 \geq \mathrm{D}>-6$

$-2 \geq D>-4$

$2 \geq D>-2$

D $>2$
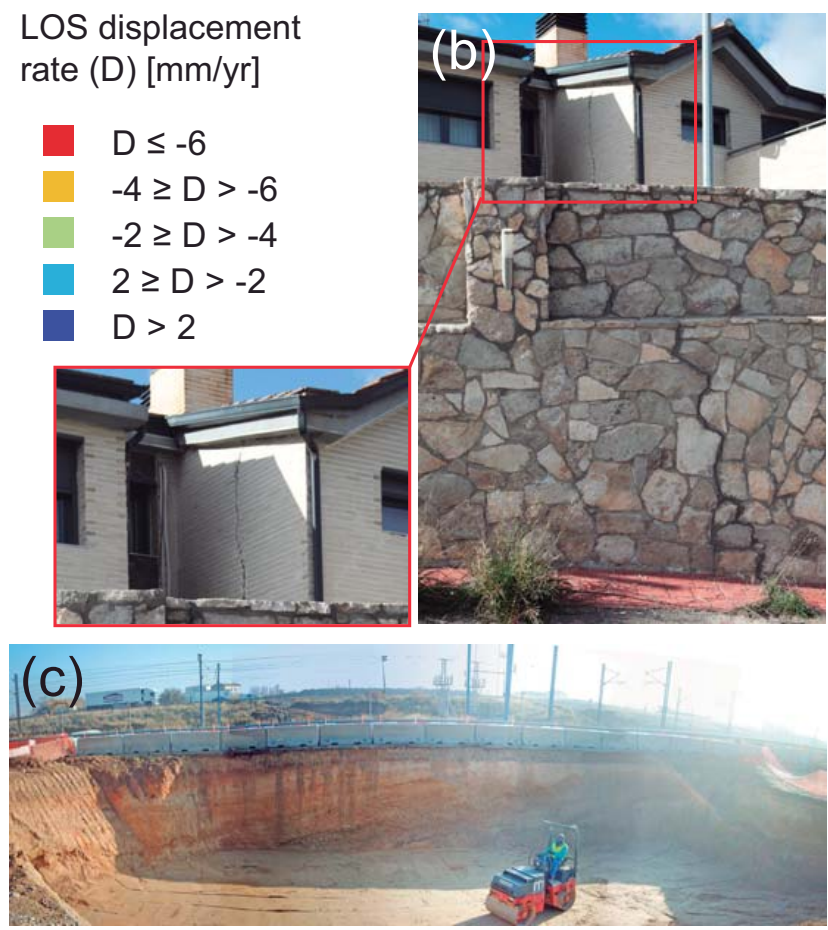

(d)

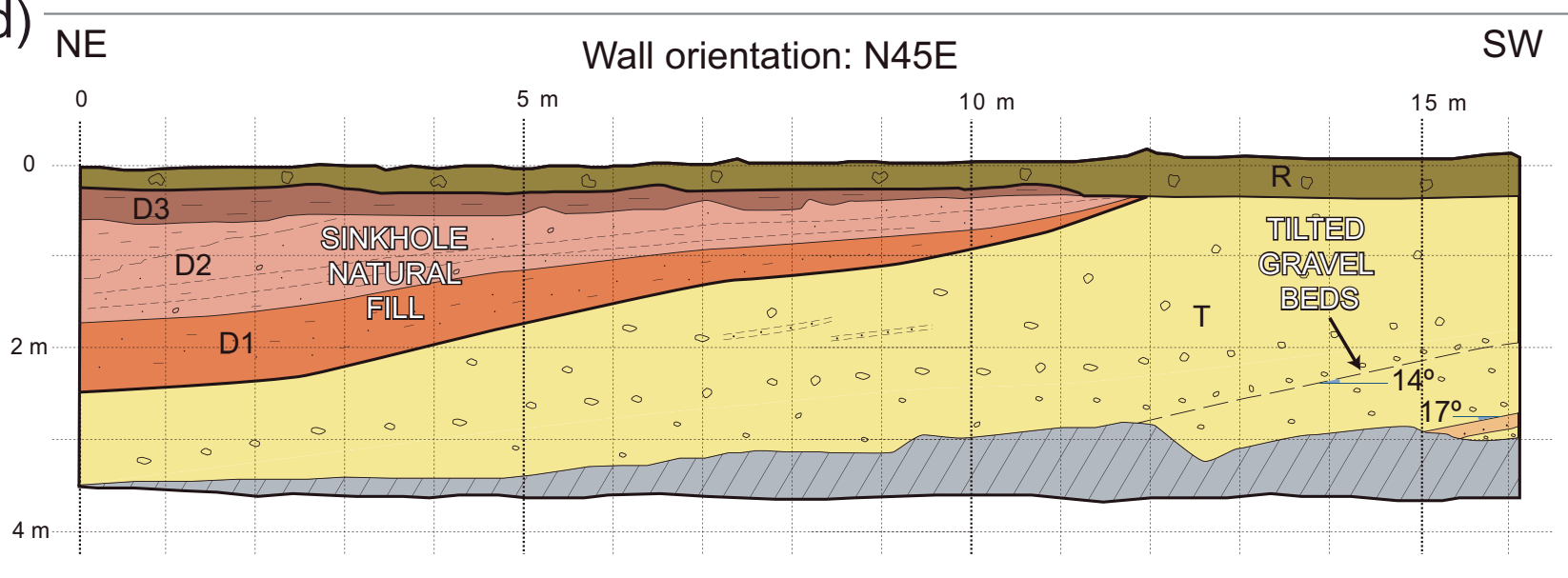

R Poorly sorted pebble-cobble gravel with light brown sandy matrix (man-made deposit)

D3 Reddish brown soil developed on unit D2.

D2 Well-bedded pebble-granule-gravel with silty sand matrix and abundant secondary carbonate.

D1 Massive reddish brown silt with scattered clast and strong bioturbation.

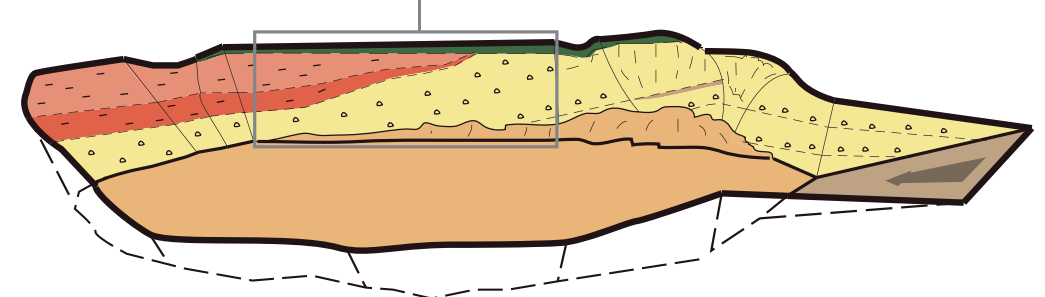

Crudely bedded, rounded pebble-cobble-gravel with sandy matrix and lenticular sand beds (fluvial terrace)

Figure 5. Evidence of karst subsidence associated with the track of the Madrid-Zaragoza high-speed railway. (a) Orthoimage of 2009 with ENVISAT DInSAR PS data indicating the main sinkholes and large karst depressions. (b) Cracks on a house where ENVISAT DInSAR map indicate subsidence. (c) General view of the excavation indicated in (a). (d) Log and scheme of the walls of the excavation. Note the wedging-out of the sinkhole fill and the tilted terrace gravel beds. 
Table 1. Main characteristics of the SAR data sets and DInSAR deformation profiles.

\begin{tabular}{|c|c|c|c|}
\hline & & ENVISAT & ALOS \\
\hline \multirow{12}{*}{ 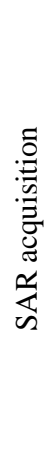 } & Band/polarization & $\mathrm{C} / \mathrm{VV}$ & $\mathrm{L} / \mathrm{HH}$ \\
\hline & Wavelength $(\mathrm{cm})$ & 5.6 & 23.6 \\
\hline & Incidence angle & 23 & 38.7 \\
\hline & Revisiting period (days) & 35 & 46 \\
\hline & Orbital track/frame & $58 / 829$ & $665 / 820$ \\
\hline & Acquisition geometry & Ascending & Ascending \\
\hline & Pixel size $(\mathrm{m})$ radar geometry & $4 \times 10$ & $8 \times 4$ \\
\hline & Data set period & May 2003-Sept 2010 (7.38 years) & Feb 2007-Apr 2010 (3.15 years) \\
\hline & Temporal span between two acquisitions (days) & & \\
\hline & Mean & 96 & 96 \\
\hline & Maximum & 700 & 414 \\
\hline & Minimum & 5 & 46 \\
\hline \multirow{6}{*}{ 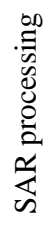 } & Number of SAR images & 29 & 13 \\
\hline & Number of interferograms & 61 & 78 \\
\hline & Maximum spatial baseline (m) & 138 & 393 \\
\hline & Maximum temporal baseline (days) & 1050 & 1150 \\
\hline & DEM (pixel size) & GIS Oleícola (20 m) & GIS Oleícola (20 m) \\
\hline & Coherence threshold & 0.46 & 0.4 \\
\hline \multirow{16}{*}{ 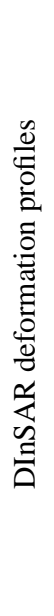 } & Railway line & Madrid-Barcelona & Castejón-Zaragoza \\
\hline & Length $(\mathrm{km})$ & 3.75 & 4 \\
\hline & Width (m) & 50 & 70 \\
\hline & No. of measurement points & 436 & 198 \\
\hline & Type of point & Persistent scatterer & Pixel $(\sim 25 \mathrm{~m})$ \\
\hline & Density of measurement points (points km ${ }^{-1}$ ) & 116.3 & 49.5 \\
\hline & LOS displacement rate $\left(\mathrm{mm} \mathrm{yr}^{-1}\right)$ & & \\
\hline & Mean & -1.4 & -2.4 \\
\hline & Maximum value (uplift) & 2.1 & 1 \\
\hline & Minimum value (subsidence) & -8.6 & -9.7 \\
\hline & Standard deviation & 1.3 & 1.8 \\
\hline & Cumulative LOS displacement (mm) & & \\
\hline & Mean & -11.1 & -7 \\
\hline & Maximum value (uplift) & 12 & 3.9 \\
\hline & Minimum value (subsidence) & -57.6 & -28.9 \\
\hline & Standard deviation & 9.5 & 5.2 \\
\hline
\end{tabular}

\section{Discussion}

The presented data illustrate that DInSAR offers promising potential for monitoring railways that are affected by sinkhole activity and dissolution-induced subsidence. This postulate is supported by two relevant aspects of our investigation. (1) There is a good spatial correlation between the deformation values measured by DInSAR and unambiguous field evidence of active subsidence associated with sinkholes. (2) We obtained good results using InSAR data derived from a regional investigation (see Galve et al., 2015). Detailed analyses focused on railway tracks or on specific sections of the infrastructure should provide higher density and more accurate deformation data than in the profiles presented in this paper.

Railways are linear features that are commonly positioned on relatively flat surfaces that act as adequate reflectors for the spaceborne SAR systems, providing spatially dense and temporarily stable coherent scatterers (Hanssen and van Leijen, 2009; Shi et al., 2014). Chen et al. (2012) illustrate the strong backscattering of railways in ALOS PALSAR and ENVISAT ASAR amplitude images, compared with the surrounding features. The density of natural reflection points depends on the land cover, the number of images used in the InSAR analysis, the adopted processing parameters and algorithm type, the selected coherence threshold and the spatial resolution of radar imagery (Wasowsky and Bovenga, 2014). In our case, ENVISAT displacement points cover a larger area in the Madrid-Zaragoza profiles (NW-SE orientation) than the ALOS displacement data. On the contrary, ALOS data provided the best distribution of measured points along the Castejón-Zaragoza stretch (NE-SW orientation). Apparently, this difference could be attributed to the relative orien- 
tation of the railway tracks with respect to the flight path of sensors. However, both the ENVISAT and ALOS data correspond to ascending paths and, consequently, the differences observed between the two DInSAR displacement rate maps cannot be related to the course of the satellites. Ge et al. (2008) and Shi et al. (2010) have obtained deformation sequences covering long time spans analysing PSs along railways. Shi et al. (2010) measured numerous minor and locally distributed displacements that were not detected by levelling. Chen et al. (2012) obtained a higher density of PSs with ALOS PALSAR data than with ENVISAT ASAR data. This was probably due to the longer wavelength of the former and the higher critical baseline applied to generate the ALOS interferograms of the small baseline subset (SBAS) method (Lanari et al., 2004). This resulted in higher coherence, especially in zones with high deformation gradients and in manmade features such as the railway embankment. Lanari et al. (2004) inferred that the difference in the distribution of PSs derived from L- and C-band data are controlled by their different scattering mechanisms. In the PALSAR results, the railway embankment was more easily detected because of its resolution $(10 \mathrm{~m})$. Man-made linear features were dominated by the dihedral scattering and resulted in a high density of PS points in the PALSAR results. For ENVISAT data, despite the strong backscattering of the railway, motion was not detected using the PS method, probably due to the noise caused by the scattering mechanism of instable land surfaces.

\section{Conclusions and final considerations}

DInSAR techniques allowed the detection of previously unknown settlement in several stretches of two major railway lines of NE Spain. The area in the outskirts of Zaragoza is severely affected by evaporite karst subsidence. This deformation was detected thanks to medium-resolution surface velocity maps generated through the analysis of archived data of the ENVISAT and ALOS SAR missions. The results show that DInSAR methods allow deformation of railways to be identified and monitored, that may otherwise compromise both serviceability and safety.

DInSAR velocity maps coupled with detailed geomorphological maps may help in the identification and characterization of the railway stretches affected by active deformation that may require site-specific monitoring. These stretches may be controlled by using real-time advanced ground-based monitoring techniques such as motorized total station systems that measure prisms attached directly to the structure, time-domain reflectometry (TDR) coaxial cable sensors (cf., O'Connor et al., 2004) or GB-InSAR (cf., Intrieri et al., 2015). DInSAR also could be an alternative to these expensive techniques where catastrophic collapse can be ruled out and the ground deformation does not show dangerous subsidence rates (according to the admissible deformation of the railway track). Site-specific investigations combining more adequate and higher-resolution SAR data with ground references (e.g. corner reflectors, GPS benchmarks) may provide a very precise monitoring system. PS detection in linear infrastructures is improving substantially by using highresolution data (e.g. CosmoSkyMed, TerraSAR-X) (Ge et al., 2013; Nutricato et al., 2013; Yu et al., 2013; Luo et al., 2014). High-resolution imagery can provide a point density 10 times higher than medium-resolution data (Bovenga et al., 2012). Yu et al. (2013) found dense PSs in highways and railways using high-resolution TerraSAR-X data due to the presence of numerous stable objects distributed along the infrastructure, such as lamps, stones or fences. Future studies in our study area should focus on the monitoring of deformation using TerraSAR-X and COSMO-SkyMed data coupled with other ground-based measurements.

Acknowledgements. This research has been funded by the Spanish national projects CGL2010-16775, AGL2012-40100 and CGL2013-40867-P (Spanish Ministry of Economy and Competitiveness and FEDER), the Regional projects 2012/GA-LC-021 and 2012/GA LC 036 (DGA-La Caixa) and the European Interreg IV B SUDOE project DO-SMS-SOE1/P2/F157. Jorge Pedro Galve was contracted under the DGA-La Caixa project and is now developing his work thanks to a "Juan de la Cierva" research contract from the Spanish Ministry of Economy and Competitiveness. SPN maps (derived from ENVISAT and ALOS data) were produced by Altamira Information S.L. (Spain). The 2009 orthophotos are products of the National Geographic Institute of Spain (Instituto Geográfico Nacional) available at: http://centrodedescargas.cnig.es/CentroDescargas/index.jsp. Comments by two anonymous reviewers and suggestions by the journal's editor, Mario Parise, helped us improve this work.

Edited by: M. Parise

Reviewed by: two anonymous referees

\section{References}

Abelson, M., Baer, G., Shtivelman, V., Wachs, D., Raz, E., Crouvi, O., Kurzon, I., and Yechieli, Y.: Collapsesinkholes and radar interferometry reveal neotectonics concealed within the Dead Sea basin, Geophys. Res. Lett., 30, 1545, doi:10.1029/2003GL017103, 2003.

Acero, P., Auqué, L. F., Galve, J. P., Gutiérrez, F., Carbonel, D., Gimeno, M. J., Yechieli, Y., Asta, M. P., and Gómez, J. B.: Evaluation of geochemical and hydrogeological processes by geochemical modeling in an area affected by evaporite karstification, J Hydrol., doi:10.1016/j.jhydrol.2015.07.028, online first, 2015.

Al-Fares, R.: The Utility of Synthetic Aperture Radar (SAR) interferometry in monitoring sinkhole subsidence: subsidence of the Devil's Throat Sinkhole Area (Nevada, USA), in: Proceedings of the 10th Multidisciplinary Conference on Sinkholes and the Engineering and Environmental Impacts of Karst, edited by: Beck, B. F., Geo Institute ASCE, San Antonio, Texas, US, 541-547, 2005. 
Baer, G., Schattner, U., Wachs, D., Sandwell, D., Wdowinski, S., and Frydman, S.: The lowest place on Earth is subsiding - An InSAR (interferometric synthetic aperture radar) perspective, Geol. Soc. Am. Bull., 114, 12-23, doi:10.1130/00167606(2002)114<0012:TLPOEI>2.0.CO;2, 2002.

Bianchini, S., Herrera, G., Mateos, R. M., Notti, D., Garcia, I., Mora, O., and Moretti, S.: Landslide activity maps generation by means of persistent scatterer interferometry, Remote Sens., 5 , 6198-6222, doi:10.3390/rs5126198, 2013.

Bovenga, F., Wasowski, J., Nitti, D. O., Nutricato, R., and Chiaradia, M. T.: Using COSMO/SkyMed X-band and ENVISAT Cband SAR interferometry for landslides analysis, Remote Sens. Environ., 119, 272-285, doi:10.1016/j.rse.2011.12.013, 2012.

Castañeda, C., Gutiérrez, F., Manunta, M., and Galve, J. P.: DInSAR measurements of ground deformation by sinkholes, mining subsidence, and landslides, Ebro River, Spain, Earth Surf. Proc. Land., 34, 1562-1574, doi:10.1002/esp.1848, 2009.

Castañeda, C., Pourthié, N., and Souyris, J.-C.: Dedicated SAR interferometric analysis to detect subtle deformation in evaporite areas around Zaragoza, NE Spain, Int. J. Remote Sens., 32, 1861-1884, doi:10.1080/01431161003631584, 2011.

Chen, F., Lin, H., Li, Z., Chen, Q., and Zhou, J.: Interaction between permafrost and infrastructure along the Qinghai-Tibet Railway detected via jointly analysis of C- and L-band small baseline SAR interferometry, Remote Sens. Environ., 123, 532540, doi:10.1016/j.rse.2012.04.020, 2012.

Chen, F., Lin, H., Zhou, W., Hong, T., and Wang, G.: Surface deformation detected by ALOS PALSAR small baseline SAR interferometry over permafrost environment of Beiluhe section, Tibet Plateau, China, Remote Sens. Environ., 138, 10-18, doi:10.1016/j.rse.2013.07.006, 2013.

Closson, D., Karaki, N. A., Klinger, Y., and Hussein, M. J.: Subsidence and sinkhole hazard assessment in the Southern Dead Sea area, Jordan, Pure Appl. Geophys., 162, 221-248, doi:10.1007/s00024-004-2598-y, 2005.

Closson, D., Karaki, N. A., Milisavljevic, N., Hallot, F., and Acheroy, M.: Salt-dissolution-induced subsidence in the Dead Sea area detected by applying interferometric techniques to ALOS Palsar Synthetic Aperture Radar images, Geodin. Acta, 23, 65-78, doi:10.3166/ga.23.65-78, 2010.

Crosetto, M., Biescas, E., Duro, J., Closa, J., and Arnaud, A.: Generation of advanced ERS and Envisat interferometric SAR products using the stable point network technique, Photogramm. Eng. Rem. S., 74, 443-450, 2008.

Ferretti, A., Ferrucci, F., Prati, C., and Rocca, F.: SAR analysis of building collapse by means of the permanent scatterers technique, in: Geoscience and Remote Sensing Symposium - The Role of Remote Sensing in Managing the Environment. Proceedings. IGARSS 2000. IEEE 2000 International, 24 July 2000-28 July 2000, Honolulu, HI, IEEE, 7, 3219-3221, doi:10.1109/IGARSS.2000.860388, 2000.

Ferretti, A., Basilico, M., Novali, F., and Prati, C.: Possibile utilizzo di dati radar satellitari per individuazione e monitoraggio di fenomeni di sinkholes, Stato dell'arte sullo studio dei fenomeni di sinkhole e ruolo delle amministrazioni statali e locali nel governo del territorio, APAT, Roma, 331-340, 2004.

Galve, J. P., Gutiérrez, F., Lucha, P., Bonachea, J., Remondo, J., Cendrero, A., Gutiérrez, M., Gimeno, M. J., Pardo, G., and Sánchez, J. A.: Sinkholes in the salt- bearing evaporite karst of the Ebro River valley upstream of Zaragoza city (NE Spain), Geomorphology, 108, 145-158, doi:10.1016/j.geomorph.2008.12.018, 2009.

Galve, J. P., Castañeda, C., Gutiérrez, F., and Herrera, G.: Assessing sinkhole activity in the Ebro Valley mantled evaporite karst using advanced DInSAR, Geomorphology, 229, 30-44, 2015.

Ge, D., Wang, Y., Guo, X., Wang, Y., and Xia, Y.: Land Subsidence Investigation Along Railway Using Permanent Scatterers SAR Interferometry, in: Geoscience and Remote Sensing Symposium, 2008. IGARSS 2008. IEEE International, 711 July 2008, Boston, Massachusetts, USA, 2, II-1235-II-1238, doi:10.1109/IGARSS.2008.4779225, 2008.

Ge, D., Wang, Y., Zhang, L., Xia, Y., Wang, Y., and Guo, X.: Using permanent scatterer InSAR to monitor land subsidence along High Speed Railway-the first experiment in China, Proceedings of "Fringe 2009 Workshop", 30 November-4 December 2009, Frascati, Italy, 2009.

Ge, D., Wang, Y., Zhang, L., Li, M., and Guo, X.: Integrating medium and high resolution PSInSAR data to monitor terrain motion along large scale manmade linear features - a case study in Shanghai, in: Geoscience and Remote Sensing Symposium (IGARSS), 2013 IEEE International, 21-26 July 2013, Melbourne, Australia, IEEE, 4034-4037, doi:10.1109/IGARSS.2013.6723718, 2013.

Gourc, J. P., Villard, P., and Giraud, H.: Full scale experimentation of discontinuous subsidence for railway and motorway embankments, in: Proceedings of the Twelfth European Conference on Soil Mechanics and Geotechnical Engineering; Geotechnical Engineering for Transportation Infrastructure; Theory and Practice, Planning and Design, Construction and Maintenance, 7-10 June 1999, Amsterdam, Netherlands, edited by: Barends, F. B. J., Lindenberg, J., Luger, H. J., Quelerij, L., and Verruijt, A., A.A. Balkema, Rotterdam, 1789-1794, 1999.

Guerrero, J., Gutiérrez, F., Bonachea, J., and Lucha, P.: A sinkhole susceptibility zonation based on paleokarst analysis along a stretch of the Madrid-Barcelona high-speed railway built over gypsum- and salt-bearing evaporites (NE Spain), Eng. Geol., 102, 62-73, 2008.

Gutiérrez, F., Galve, J. P., Guerrero, J., Lucha, P., Cendrero, A., Remondo, J., Bonachea, J., Gutiérrez, M., and Sánchez, J. A.: The origin, typology, spatial distribution and detrimental effects of the sinkholes developed in the alluvial evaporite karst of the Ebro River valley downstream of Zaragoza city (NE Spain), Earth Surf. Processes, 32, 912-928, 2007.

Gutiérrez, F., Guerrero, J., and Lucha, P.: A genetic classification of sinkholes illustrated from evaporite paleokarst exposures in Spain, Environ. Geol., 53, 993-1006, doi:10.1007/s00254-0070727-5, 2008.

Gutiérrez, F., Galve, J. P., Lucha, P., Bonachea, J., Jordá, L., and Jordá, R.: Investigation of a large collapse sinkhole affecting a multi-storey building by means of geophysics and the trenching technique (Zaragoza city, NE Spain), Environ. Geol., 58, 11071122, doi:10.1007/s00254-008-1590-8, 2009.

Gutiérrez, F., Galve, J. P., Lucha, P., Castañeda, C., Bonachea, J., and Guerrero, J.: Integrating geomorphological mapping, trenching, InSAR and GPR for the identification and characterization of sinkholes: A review and application in the mantled evaporite karst of the Ebro Valley (NE Spain), Geomorphology, 134, 144156, doi:10.1016/j.geomorph.2011.01.018, 2011. 
Gutiérrez, F., Parise, M., De Waele, J., and Jourde, H.: A review on natural and human-induced geohazards and impacts in karst, Earth-Sci. Rev., 138, 61-88, doi:10.1016/j.earscirev.2014.08.002, 2014.

Gutiérrez, F., Mozafari, M., Carbonel, D., Gómez, R., and Raeisi, E.: Leakage problems in dams built on evaporites. The case of $\mathrm{La}$ Loteta Dam (NE Spain), a reservoir in a large karstic depression generated by interstratal salt dissolution, Eng. Geol., 185, 139154, doi:10.1016/j.enggeo.2014.12.009, 2015.

Hanssen, R. F. and van Leijen, F. J.: One-dimensional radar interferometry for line infrastructure, in: Geoscience and Remote Sensing Symposium, 2009 IEEE International, IGARSS 2009, 12-17 July 2009, Cape Town, South Africa, 5, V-9-V-12, doi:10.1109/IGARSS.2009.5417745, 2009.

Hung, W.-C., Hwang, C., Chang, C.-P., Yen, J.-Y., Liu, C.-H., and Yang, W.-H.: Monitoring severe aquifer-system compaction and land subsidence in Taiwan using multiple sensors: Yunlin, the southern Choushui River Alluvial Fan, Environ. Earth Sci., 59, 1535-1548, doi:10.1007/s12665-009-0139-9, 2010.

Intrieri, E., Gigli, G., Nocentini, M., Lombardi, L., Mugnai, F., Fidolini, F., and Casagli, N.: Sinkhole monitoring and early warning: An experimental and successful GB-InSAR application, Geomorphology, 241, 304-314, doi:10.1016/j.geomorph.2015.04.018, 2015.

Lanari, R., Mora, O., Manunta, M., Mallorquí, J. J., Berardino, P., and Sansosti, E.: A small-baseline approach for investigating deformations on full-resolution differential SAR interferograms, IEEE Trans. Geosci. Remote Sens., 42, 1377-1386, doi:10.1109/TGRS.2004.828196, 2004

Luo, Q., Perissin, D., Lin, H., Zhang, Y., and Wang, W.: Subsidence Monitoring of Tianjin Suburbs by TerraSAR-X Persistent Scatterers Interferometry, in: Selected Topics in Applied Earth Observations and Remote Sensing, IEEE Journal of, 7, 1642-1650, doi:10.1109/JSTARS.2013.2271501, 2014

Massonnet, D. and Feigl, K. L.: Radar interferometry and its application to changes in the Earth's surface, Rev. Geophys., 36(4), 441-500, doi:10.1029/97RG03139, 1998.

Meisina, C., Zucca, F., Notti, D., Colombo, A., Cucchi, A., Savio, G., Giannico, C., and Bianchi, M.: Geological interpretation of PSInSAR Data at regional scale, Sensors, 8, 7469-7492, doi:10.3390/s8117469, 2008.

Nof, R. N., Baer, G., Ziv, A., Raz, E., Atzori, S., and Salvi, S.: Sinkhole precursors along the Dead Sea, Israel, revealed by SAR interferometry, Geology, 41, 1019-1022, 2013.

Nutricato, R., Nitti, D. O., Bovenga, F., Refice, A., Wasowski, J., and Chiaradia, M. T.: C/X-band SAR interferometry applied to ground monitoring: examples and new potential, in: Proc. SPIE, 8891, 88910C-88910C-9, doi:10.1117/12.2029096, 2013.

O’Connor, K., Crawford, J., Price, K. and Sharpe, R.: Using Time-Domain Reflectometry for Real-Time Monitoring of Subsidence over an Inactive Mine in Virginia, Transportation Research Record: Journal of the Transportation Research Board, 1874, 147-154, doi:10.3141/1874-16, 2004.

Paine, J. G., Buckley, S. M., Collins, E. W., and Wilson, C. R.: Assessing Collapse Risk in Evaporite Sinkhole-prone Areas Using Microgravimetry and Radar Interferometry, J. Environ. Eng. Geoph., 17, 75-87, doi:10.2113/JEEG17.2.75, 2012.

Pueyo Anchuela, Ó., Casas Sainz, A. M., Pocoví Juan, A., and Gil Garbí, H.: Assessing karst hazards in urbanized areas.
Case study and methodological considerations in the mantle karst from Zaragoza city (NE Spain), Eng. Geol., 184, 29-42, doi:10.1016/j.enggeo.2014.10.025, 2015.

Quirantes, J.: Estudio sedimentológico y estratigráfico del Terciario continental de los Monegros, Institución Fernando El Católico (CSIC), Diputación Provincial de Zaragoza, 207 pp., 1978.

Salvany, J. M., García-Veigas, J., and Ortí, F.: Glauberitehalite association of the Zaragoza Gypsum Formation (Lower Miocene, Ebro Basin, NE Spain), Sedimentology, 54, 443-467, doi:10.1111/j.1365-3091.2006.00844.x, 2007.

Sandwell, D. T., Myer, D., Mellors, R., Shimada, M., Brooks, B., and Foster, J.: Accuracy and resolution of ALOS interferometry: Vector deformation maps of the father's day intrusion at Kilauea, IEEE Trans. Geosci. Remote Sens., 46, 3524-3534, doi:10.1109/TGRS.2008.2000634, 2008.

Schäffer, U.: Hamburg, Germany, in: The Terrafirma Atlas, A compendium of results produced by the European Space Agency GMES Service Element Project Terrafirma 2003-2009, ESRIN Contract 19366/05/I-EC, edited by: Capes, R. and Marsh, S., 23, 2009.

Shi, H., Yang, S., Wei, Q., and Tan, Q.: Study on the establishment of integrated HSR subsidence monitoring system based on InSAR technique, in International Conference on Railway Engineering, ICRE2010 Proceedings, 20-21 August 2010, Beijing, China, 729-734, 2010.

Shi, X., Liao, M., Wang, T., Zhang, L., Shan, W., and Wang, C.: Expressway deformation mapping using highresolution TerraSAR-X images, Remote Sens. Lett., 5, 194-203, doi:10.1080/2150704X.2014.891774, 2014.

Simón, J. L., Soriano, M. A., Arlegui, L., and Caballero, J.: Estudio de riesgos de hundimientos kársticos en el corredor de la Carretera de Logroño, available at: http://www.zaragoza.es/contenidos/urbanismo/pgouz/memoria/ anejos/anejo03/anejo032.pdf, last access: 20 May 2015, 1998.

Simón, J. L., Soriano, M., Arlegui, L., Casas, A., Liesa, C., Pocoví, A., Gracia, J., and Salvador, T.: Evaluación del riesgo de hundimientos por dolinas en el trazado de las nuevas estructuras ferroviarias en el entorno de Zaragoza (informe complementario), available at: http://estaticos.elmundo.es/documentos/ 2003/10/03/informeave.doc, last access: 20 May 2015, 2003.

Tan, Q., Xie, C., and Yang, S.: A new surveying technology for railway subgrade settlement deformation monitoring: a case study, in: ICRE2010- International Conference on Railway Engineering Proceedings, 20-21 August 2010, Beijing, China, 404-407, 2010.

Waltham, T., Bell, F., and Culshaw, M.: Sinkholes and Subsidence, Praxis Publishing, Springer, Chichester, UK, 2005.

Wasowski, J. and Bovenga, F.: Investigating landslides and unstable slopes with satellite Multi Temporal Interferometry: Current issues and future perspectives, Eng. Geol., 174, 103-138, doi:10.1016/j.enggeo.2014.03.003, 2014.

Wu, H., Zhang, Y., Zhang, J., and Chen, X.: Mapping deformation of man-made linear features using DInSAR technique, in: ISPRS TC VII Symposium - 100 Years ISPRS, 5-7 July 2010, Vienna, Austria, edited by: Wagner, W. and Székely, B., IAPRS, Vol. XXXVIII, Part 7A, 293-297, 2010.

Xuedong, Z., Daqing, G., Weiyu, M., Ling, Z., Dapeng, Y., and Xiaofang, G.: Study the land subsidence along JingHu highway (Beijing-Hebei) using PS-InSAR tech- 
nique, Geosci. Remote Sens. Symp. (IGARSS), 2011 IEEE Int., 24-29 July 2011, Vancouver, Canada, 1608-1611, doi:10.1109/IGARSS.2011.6049538, 2011.

Yu, B., Liu, G., Zhang, R., Jia, H., Li, T., Wang, X., Dai, K., and Ma, D.: Monitoring subsidence rates along road network by persistent scatterer SAR interferometry with high-resolution TerraSAR-X imagery, Journal of Modern Transportation, 21, 236-246, doi:10.1007/s40534-013-0030-y, 2013.
Zhang, H., Tao, L., Wang, C., and Tang, Y.: Ground deformation detection along Beijing-Tianjin intercity railway using advanced network multi-baseline DInSAR, Wavelet Anal. Pattern Recognit. (ICWAPR), 2010 Int. Conf., Qingdao, China, 11-14 July 2010, 222-226, doi:10.1109/ICWAPR.2010.5576333, 2010. 